Studia i materiały z dziedzictwa kulturowego Torunia i regionu, t. 1: STARE I NOWE DZIEDZICTWO TORUNIA,

Toruń 2013

http://dx.doi.org/10.12775/SiMzDzKTiR_T1.2013.009

Juliusz Raczkowski

(IZIK UMK, TORUŃ)

Monika Jakubek-Raczkowska

(IZIK UMK, TORUŃ)

\title{
Gotyckie rzeźby z kościoła w Świerczynkach Przyczynek do badań nad średniowiecznym dziedzictwem Torunia*
}

Parafia pw. św. Jana Chrzciciela i św. Jana Ewangelisty we wsi Świerczynki, położonej w odległości niecałych dwunastu kilometrów od centrum Starego Miasta Torunia (na dawnym szlaku handlowym łączącym Toruń i Chełmno), od początków swego istnienia była integralnie powiązana $\mathrm{z}$ dynamicznym procesem budowy sieci parafialnej na ziemi chełmińskiej. Z czasem wpisała się też w dzieje jedynego w średniowieczu konwentu żeńskiego w Toruniu. Fundacja parafii przypadła na sam początek XIV wieku, patronat nad nią sprawował początkowo zakon krzyżacki ${ }^{1}$, który w 1345 roku przekazał to prawo toruńskim cysterkom-benedyktynkom². Od założenia klasztoru w $1311 \mathrm{roku}^{3}$ cieszyły się one szczególnym poparciem terytorialnego władcy; przyznanie patronatu przypadło na okres szczególnego rozkwitu ich konwentu, jaki nastąpił w latach 1330-13504. Folwark w Świerczynkach

* Poruszane tu kwestie są efektem studiów, prowadzonych przez autorów przed paroma laty nad warsztatem toruńskiego Chrystusa w Grobie i pogłębianych w ramach realizacji grantu MNiSZW Księga klasztorów ziemi chełmińskiej pod kierunkiem dr. hab. Piotra Olińskiego.

1 Waldemar ROZYNKOWSKI, Powstanie i rozwój sieci parafialnej $w$ diecezji chetmińskiej $w$ czasach panowania zakonu krzyżackiego, (Roczniki TNT, R. 89, z. 2), Toruń 2000, s. 171-172.

2 TAMŻE, s. 171.

3 Piotr OLIŃSKI, Motywy fundacji klasztorów przez zakon krzyżacki w Prusach w świetle dokumentów fundacyjnych (ze szczególnym uwzględnieniem dokumentów fundacyjnych żeńskiego klasztoru benedyktyńskiego w Królewcu i klasztoru augustianów-eremitów w Chojnicach), [w:] Kancelarie krzyżackie. Stan badań i perspektywy badawcze. Materiały z międzynarodowej konferencji naukowej Malbork 18-19 X 2001, red. J. TRUPINDA, Malbork 2002, s. 191-209, zwł. s. 193-194.

4 Zob. odpowiednie dokumenty w Urkundenbuch des Bisthums Culm, Bd 1: Das Bisthum unter dem Deutschen Orden 1243-1466, Hg. Carl Peter WOELKY, Danzig 1885: W 1335 r. papież Benedykt XII wziął mniszki w opiekę stolicy apostolskiej (nr 251), w 1336 r. dołączyły do wspólnoty modlitewnej franciszkanów prowincji saskiej (nr 252). W tym też okresie uzyskały od wielkiego mistrza Dietricha z Altenburga (1335-41) prawo patronatu nad toruńskim kościołem św. Jakuba, potwierdzone dokumentem Ludolfa Königa z 1345 (nr 281); wcześniej - w 1330 r., konwent otrzymał też patronat nad kościołem parafialnym, kaplicą NMP i dobrami w Szynwałdzie (nr 229). 
należał do mniszek prawdopodobnie aż do $1834 \mathrm{roku}^{5}$.

Kościół świerczyński został wzniesiony w drugiej ćwierci XIV wieku6 . Pod względem koncepcji architektonicznej, budowla należy do grupy jednonawowych kościołów wiejskich, licznie wznoszonych na ziemi chełmińskiej w pierwszej połowie XIV wieku ${ }^{7}$ Teresa Mroczko wyróżniła wśród nich grupę budowli „trójczłonowych”, z wielobocznie zamkniętym prezbiterium, nawą i wieżą od zachodu. Reprezentująca ten typ budowla świerczyńska jest w tej grupie najstarsza ${ }^{8}$, a budowana była zapewne przez zespół muratorów toruńskich, obeznanych z rozwiązaniami architektonicznymi zastosowanymi w kościele św. Jakuba i u dominikanów toruńskich ${ }^{9}$. Kościół miał ucierpieć podczas wojny trzynastoletniej, był też kilkakrotnie przebudowywany ${ }^{10}$. Jego wyposażenie, pochodzące z czasów nowożytnych (przełom XVII i XVIII wieku), należy do najlepszych artystycznie zespołów tego typu na ziemi chełmińskiej ${ }^{11}$. W świątyni zachował się poza tym niejednorodny zespół pięciu, dobrej klasy rzeźb gotyckich o wtórnej lokalizacji w przestrzeni liturgicznej. Niektóre z nich wiązane są $\mathrm{w}$ dotychczasowej literaturze z toruńskimi benedyktynkami.

Za wyjątkiem wolnostojącej Piety, umieszczonej w niszy ściennej prezbiterium po stronie północnej, gotyckie zabytki zostały wtórnie włączone w strukturę późnobarokowej nastawy ołtarza głównego, datowanego inskrypcją na 1696 rok (il. 1). Rzeźby należą do dwóch grup stylistycznych i przynajmniej trzech zespołów warsztatowych. Pieta oraz dwa popiersia świętych (w tym herma relikwiowa św. biskupa) na gzymsie nastawy, o zbliżonych cechach formalnych, to słabo jak dotychczas rozpoznane dzieła powstałe najpewniej na początku $\mathrm{XV}$ wieku. W dotychczasowych badaniach więcej uwagi poświęcono natomiast późnogotyckim rzeźbom świerczyńskim - kultowej figurze Madonny z Dzieciątkiem w centrum nastawy ołtarzowej oraz odrębnej warsztatowo grupie Pietas Domini w jej zwieńczeniu. Rzeźby te, datowane na przełom XV i XVI wieku, były przedmiotem studiów m. in. Janiny Kruszelnic-

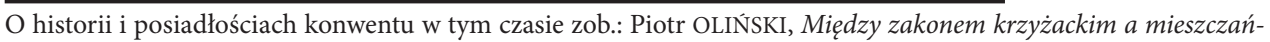
stwem pruskim. Uwagi o klasztorach żeńskich w wielkich miastach pruskich, [w:] Cysterki w dziejach i kulturze ziem polskich, dawnej Rzeczypospolitej i Europy Środkowej. Materiały z siódmej Międzynarodowej Konferencji Cystersologów odbytej z okazji 800 rocznicy fundacji opactwa cysterek w Trzebnicy. Trzebnica, 18-21 września 2002 r., red. A. M. WYRWA, A. KIEŁBASA, J. SWASTEK, Poznań 2004, s. 883-897, zwł. 890-894 oraz Jolanta KUREK, Klasztory cysterek-benedyktynek w Chetmnie, Toruniu i Królewcu od średniowiecza do czasów potrydenckich. Powiązania i cechy wspólne, „Studia Pelplińskie” 37 (2006), s. 295-317, zwł. s. 300-301.

5 Marzena OLESIŃSKA, Posiadłości klasztoru benedyktynek toruńskich w czasach ksieni Zofii Dulskiej, „Studia Pelplińskie" 37 (2006), s. 181-196, zwł. s. 195.

6 Takie uściślenie datowania proponuje Christopher HERRMANN, Mittelalterliche Architektur im Preußenland. Untersuchungen zur Frage der Kunstlandschaft und-geographie, Petersberg 2007, s. 743.

7 Teresa MROCZKO, Architektura gotycka na Ziemi Chetmińskiej, Warszawa 1980, s. 259.

8 TAMŻE, s. 266.

9 TAMŻE, s. 286.

10 Katalog Zabytków Sztuki w Polsce, t. 11, Województwo bydgoskie, z. 16: Powiat toruński, oprac. Tadeusz CHRZANOWSKI, Marian KORNECKI, Warszawa 1972 [dalej cyt. KZSP 11/16], s. 63.

11 TAMŻE, s. X-XI. 
kiej $^{12}$ i Andrzeja Wozińskiego ${ }^{13}$, którzy wiązali je - co w sposób oczywisty nasuwa lokalizacja wsi - z warsztatem toruńskim.

Spośród wspomnianych dzieł, jedynie statua Madonny (il. 2 a, b) wydaje się od początku związana z parafią w Świerczynkach. Wykonana w kręgu oddziaływania mistrza toruńskiego ołtarza św. Wolfganga, jest ona jednym z pięciu przykładów wyjątkowej redakcji ikonograficznej Regina Coeli, zachowanych na ziemi chełmińskiej ${ }^{14}$ : wyidealizowana Maria, o długich, opadających na ramiona włosach, upozowana we frontalnej, nieco poruszonej pozie, unosi przed sobą oburącz wpółleżące, nagie Dzieciątko. U jej stóp - opartych na półksiężycu - znajdują się dwie drobne figurki aniołów. Figury, reprezentujące ten szczególny typ „Assunty-Niewiasty Apokaliptycznej”, jaki wyraźnie wyłania się z zespołu bardziej standardowych koncepcji ikonograficznych późnego gotyku w państwie zakonnym, koncentrują się wokół podominikańskiej Madonny Różańcowej w kościele św. Jakuba w Toruniu oraz Madonny z dawnego ołtarza głównego katedry fromborskiej. Janina Kruszelnicka uznała zabytek świerczyński za bliższy tej drugiej ${ }^{15}$, choć jego formę - chyba nie do końca słusznie oceniła surowo, jako „zludowiałą”16.

Z figurą tą wiązać można wzmiankę w protokole wizytacyjnym biskupa Andrzeja Olszowskiego z trzeciej ćwierci XVII wieku, który wymienia w ołtarzu głównym świerczyńskiego kościoła: „B. V. statuam non invenuste sculptam”17. Zaistnienie zbliżonej typologicznie figury w wiejskim kościele w podtoruńskiej Grzywnie wskazuje, że ów rzadki wariant przedstawienia maryjnego zidentyfikowany przez Kruszelnicką, pojawiał się w wystrojach kościołów wiejskich w tym regionie. Ołtarz, w którym Madonna świerczyńska znajdowała się w okresie wizytacji, nie był jednak tożsamy z obecnym, późnobarokowym; określony został jako „Tiliciano tempore concinnata” ${ }^{18}$. Było to więc przypuszczalnie retabulum manierystyczne z końca XVI w., skądinąd - także wtórne, ale już w nim figura ozdobiona była

12 Janina KRUSZELNICKA, Dwie gotyckie figury św. Barbary z kaplicy w Barbarce pod Toruniem, „Rocznik Muzeum Okręgowego w Toruniu”, 2 (1967), z. 3/4, s. 115-151; TAŻ, Regina Coeli - grupa rzeźb późnogotyckich w Ziemi Chełmińskiej, „Biuletyn Historii Sztuki”, 33/1 (1971), s. 87-91; TAŻ, Ze studiów nad rzeźbą czasów Kopernika na Ziemi Chełmińskiej, „Rocznik Muzeum Okręgowego w Toruniu”, t. 5, 1973, s. 43-82 [dalej cyt. KRUSZELNICKA 1973-a]; TAŻ, Rzeźba i malarstwo, [w:] Kultura artystyczna Ziemi Chełmińskiej w czasach Kopernika. Katalog, Toruń 1973, s. 24-46 [dalej cyt. KRUSZELNICKA 1973-b].

13 Andrzej WOZIŃSKI, Rzeźba drewniana na Pomorzu Wschodnim w latach 1450-1550, Poznań 1996 [mps dysertacji doktorskiej, Biblioteka IHS UAM w Poznaniu]; TENŻE, Artystyczne i ideowe aspekty późnogotyckiego krucyfiksu w pofranciszkańskim kościele Mariackim w Toruniu, [w:] Dzieje i skarby kościoła Mariackiego w Toruniu. Materiały z konferencji przygotowanej przez toruński odział SHS oraz IZiK UMK, Toruń 14-16 kwietnia 2005, red. K. KLUCZWAJD, Toruń 2005 [dalej cyt. DZIEJE I SKARBY 2005], s. 203-221.

14 KRUSZELNICKA 1971, s. 90-91; KRUSZELNICKA 1973-a, s. 43, 54, 64-66.

15 KRUSZELNICKA 1973-a, s. 54.

16 TAMŻE, s. 64.

17 Visitationes episcopatus Culmensis Andrea Olszowski Episcopo A. 1667-72 factae, „Fontes” (TNT Societas Literaria Torunensis) 7 (1903), s. 241 [dalej cyt. VISITATIONES]. Tożsamość rzeźby w ołtarzu ze wzmiankowanym w protokole zabytkiem uznaje KRUSZELNICKA 1973-a, s. 65, za nią także: Grażyna JURKOWLANIEC, Epoka nowożytna wobec średniowiecza. Pamiątki przeszłości, cudowne wizerunki, dzieła sztuki, („Monografie Fundacji na Rzecz Nauki Polskiej", Seria Humanistyczna), Wrocław 2008, s. 190, przyp. 55.

18 VISITATIONES, s. 241. Czas powstania tego retabulum przypadł zapewne na rządy biskupa chełmińskiego Piotra Tylickiego, a więc na lata 1595-1600. 
prawdopodobnie srebrnymi wotami ${ }^{19}$. Pierwotnie natomiast Madonna stała najpewniej w centrum gotyckiego retabulum szafiastego o dość głębokim korpusie (przypominającym toruński ołtarz św. Wolfganga) lub w centralnej niszy ołtarza, naśladującego dawny typ Viereraltar (jak retabulum fromborskie). Losy rzeźby świadczą, że świerczyński ołtarz główny był kilkakrotnie wyposażany w nową nastawę, przy czym średniowieczna figura kultowa zachowywała w kolejnych konstrukcjach poczesne miejsce, co na tych terenach nie należało do rzadkości i było specyfiką kościołów pozostających stale w kulcie katolickim ${ }^{20}$.

Zapewne przy okazji przenosin do nowego retabulum z przełomu XVII i XVIII wieku, postaci Madonny i Dzieciątka zostały ukoronowane i udekorowane srebrną, trybowaną sukienką, zdobioną floraturą i złoconymi kłosami zbóż $\dot{z}^{21}$ (il. 3). Dynamiczna draperia sukienki, zgodnie ze specyficzną modą panującą w XVIII stuleciu w warsztatach złotniczych Torunia, dostosowana została do systemu oryginalnych pofałdowań rzeźby ${ }^{22}$; mięsisty ornament na jej powierzchni był sposobem na wzbogacenie obrazu ${ }^{23}$. Można to uznać za szczególną oznakę szacunku wobec średniowiecznej substancji, ale i czci wobec jej kultowej dawności, którą poświadczają srebrne wota przybite do drewnianej tablicy ołtarza ${ }^{24}$, nadające głównemu ośrodkowi liturgicznemu w kościele specyficznej aury sanktuarium. Pokrycie postaci Dzieciątka srebrną draperią, przydanie Madonnie berła ${ }^{25}$ oraz przesłonięcie półksiężyca zmieniło jednak sens ideowy przedstawienia w duchu ikonograficznej standaryzacji, zacie-

19 Wizytacje wymieniają: „In argento [...] 7. Ornamenta imaginum B. M. V.” VISITATIONES, s. 244. Jedna z zachowanych do dziś plakiet - ażurowa, z obramieniem akantowym i osobno lanym krucyfiksem - nosi cechy złotnictwa drugiej połowy XVII wieku (KZSP 11/16, s. 65). Zespół 12 wotów świerczyńskich wzmiankuje Michał WOŹNIAK, Złotnictwo sakralne Prus Królewskich: studium typologiczno-morfologiczne, t. 1, Toruń 2012, s. 251.

20 O figurze w Świerczynkach i innych przykładach pruskich zob. Grażyna JURKOWLANIEC, Preservation and Presentation. Medieval Images and Their Early Modern Settings in the Churches of Prussia (1525-1772), [w:] Ecclesiae Ornatae. Kirchenausstattungen des Mittelalters und der frühen Neuzeit zwischen Denkmalwert und Funktionalität, (Kunsthistorische Arbeiten der Kulturstiftung der deutschen Vertriebenen, Bd. 6), Hg. G. EIMER, E. GIERLICH, M. MÜLLER, Bonn 2009, s. 291-308, zwł. s. 303.

21 Podczas niedawnej konserwacji rzeźby, odsłonięto jej snycerską strukturę. W tej chwili Madonna jest prezentowana jest w kościele bez srebrnej sukienki.

22 Jest to jeden z kilku przykładów XVIII-wiecznych sukienek złotniczych dla rzeźb (obok sukienek Madonn z Linowa Królewskiego i Nowego Miasta Lubawskiego), podążających za gotycką draperią, jakie zachowały się na ziemi chełmińskiej. Imię złotnika nie jest znane, ale zapewne związany był on z warsztatem toruńskim. Badacze złotnictwa uznają ten sposób opracowania srebrnej draperii za specyfikę tego ośrodka, zob. Tadeusz CHRZANOWSKI, Marian KORNECKI, Złotnictwo toruńskie manieryzmu i baroku-przemiany formy, [w:] Sztuka Torunia i Ziemi Chetmińskiej 1233-1815. Materiały z Sesji Naukowej zorganizowanej dla uczczenia 750-lecia Torunia w dniach 18-20 IV 1983, (Teka Komisji Historii Sztuki” 7), red. J. POKLEWSKI, Warszawa - Poznań - Toruń 1986, s. 247-272, zwł. s. 271 oraz Tadeusz CHRZANOWSKI, Marian KORNECKI, Złotnictwo toruńskie. Studium o wyrobach cechu toruńskiego od wieku XIV do 1832 roku, Warszawa 1988, s. 104 (il. 304).

$23 \mathrm{~W}$ ten sposób ornamentalne, kwiatowe bogactwo toruńskich „sukienek” srebrnych (w tym z Linowa, Torunia i Świerczynek) interpretuje WOŹNIAK 2012, s. 233-234.

24 Zabieg włączenia wotów do nastawy świerczyńskiej jako typowy dla epoki odnotowuje JURKOWLANIEC 2008, s. 188. Zgromadzone w ołtarzu plakiety, poza jedną XVII-wieczną, datowane są na wiek XVIII, zob. KZSP 1/16, s. 65. Zespół ten jest krótko omówiony w: Michał GRADOWSKI, Magdalena PIELAS, Katalog złotnictwa w zbiorze dokumentacji specjalistycznej Krajowego Ośrodka Badań i Dokumentacji Zabytków w Warszawie, cz. 1, Warszawa 2006, s. 754-754, nr kat. 592/2-11.

25 Zostało ono nienaturalnie wtopione w sukienkę ponad prawą, zgiętą w łokciu, ręką postaci - dając efekt pewnej niezborności kompozycyjnej. 
rając niuanse teologiczne wyobrażenia Niewiasty Apokaliptycznej jako Assunty.

Druga z późnogotyckich figur, zdobiących ołtarz główny w Świerczynkach, to kompozycja Pietas Domini (Paternitas) z początku XVI wieku, wyobrażająca charakterystyczny, niderlandzki wariant obrazu Trójcy św. - z Bogiem Ojcem, trzymającym w ramionach bezwładne ciało umęczonego Chrystusa (il. 4). Choć też związana ze snycerstwem toruńskim, prezentuje ona odmienny język form, niż omówiona Madonna - szlachetny, dużo bardziej wysublimowany, tchnący świadomym niderlandyzmem. Zabytek ten zaliczony został do dzieł tzw. „Mistrza Krucyfiksu Franciszkańskiego” za sprawą analogii, które łączą go z figurą Chrystusa Ubiczowanego z kościoła św. Jana, a zwłaszcza - z krucyfiksem z kościoła pofranciszkańskiego w Toruniu ${ }^{26}$. Z racji odmienności warsztatowej oraz niezgodności ikonograficznej, trudno w tym dziele widzieć pozostałość tej samej, średniowiecznej nastawy z wyposażenia kościoła, jaką jest świerczyńska Madonna; Pietas trafiła zresztą do późnobarokowej nastawy dużo później. XIX-wieczny inwentarz parafii cytowany przez Krystynę Zalską ${ }^{27}$, wymienia drewnianą statuę Boga Ojca ustawioną w jednej z wnęk wieży, na zewnątrz świątyni. Podobną praktykę wtórnego wykorzystania średniowiecznych rzeźb snycerskich można spotkać w innych kościołach na terenie państwa zakonnego ${ }^{28}$. Proweniencja rzeźby nie została ustalona; jej wmontowanie w strukturę ołtarza Zalska osadziła w końcu XIX lub na początku XX wieku, w okresie remontu kościoła ${ }^{29}$. Wprawdzie autorka nie wskazała wprost na miejsce pochodzenia figury, naprowadziła jednak na jej ewentualny związek z cysterkami-benedyktynkami, co zostało wyeksponowane przez Janinę Kruszelnicką ${ }^{30}$, która uznała za prawdopodobne, iż po drugiej wojnie szwedzkiej pobenedyktyńskie rzeźby mogły trafić do Świerczynek z toruńskiego kościoła św. Ducha.

Spośród pozostałych trzech figur w Świerczynkach jedynie Pieta wzbudzała pewne zainteresowanie badawcze, choć raczej na marginesie syntez i prac inwentaryzatorskich. Jeszcze przed drugą wojną światową eksponowano ją na wystawie polskiej sztuki gotyckiej w Warszawie, datując na połowę XIV wieku ${ }^{31}$; została też uwzględniona w studiach Gwidona

26 Jako pierwsza - Krystyna ZALSKA, Rzeźba późnogotycka w kościele parafialnym $w$ Świerczynkach, [w:] Komunikaty na sesję naukowa poświęcona dziełom sztuki Pomorza, zorganizowana z 500-lecie Pokoju Toruńskiego, Toruń 1966, s. 72-75, zwł. s. 74; zob. także Janina KRUSZELNICKA, Dwie gotyckie figury św. Barbary z kaplicy w Barbarce pod Toruniem, „Rocznik Muzeum Okręgowego w Toruniu”, 2 (1967), z. 3/4, s. 115-151, zwł. s. 137; KRUSZELNICKA 1973-b, s. 36-37 oraz hasło katalogowe TAMŻE, s. 91-92; Katarzyna KLUCZWAJD, Chrystus Ukrzyżowany, hasło kat. [w:] Ars Sacra. Dawna sztuka diecezji toruńskiej, katalog wystawy Muzeum Okregowego w Toruniu 5 XI-31 XII 1993, Toruń 1993, s. 53; WOZIŃSKI 1996, s. 305-316, nr kat. 469; WOZIŃSKI 2005, s. 220-221.

27 ZALSKA 1966, s. 73.

28 Przykładem takiej adaptacji są rzeźby Madonn z Lubieszewa i Kończewic. Madonna na lwie (ok. 1375) z kościoła pw. św. Elżbiety w Lubieszewie w czasach inwentaryzacji Bernharda Schmida (1. ćw. XX wieku) stała w niszy ściennej szczytu wschodniego nosiła jeszcze wtedy ślady polichromii. Z kolei a figura Marii z Kończewic (obecnie w Muzeum Narodowym w Gdańsku) z ołtarza opisanego w 1669 r., w bliżej nieokreślonym czasie została wtórnie umieszczona na środkowej blendzie szczytu wschodniego budowli, skąd zdjęto ją dopiero w 1907 r. i ustawiono w izbie przy zakrystii kościoła. Zob. Bernhard SCHMID, Die Bau- und Kunstdenkmäler der Provinz Westpreussen, Bd. 4, Die Bau- und Kunstdenkmäler des Kreises Marienburg, H. 14: Die Städte Neuteich und Tiegenhof und die ländlicher Ortschaften, Danzig 1919, s. 108 i 95.

29 ZALSKA 1966, s. 73.

30 KRUSZELNICKA 1973-a, s. 65-66 oraz s. 74, przyp. 117.

31 Michał WALICKI, Polska sztuka gotycka. Katalog wystawy zorganizowanej przez Towarzystwo Opieki nad 
Chmarzyńskiego ${ }^{32}$ (tu również datowana na ok. 1350 r.) i Karla Heinza Clasena ${ }^{33}$ (datowana na ostatnią ćwierć XIV wieku). Wspomnieli o niej Świechowscy w studium poświęconym nieznanym rzeźbom pomorskim, omawiając Piety z Żarnowca i Kijewa ${ }^{34}$. Figura została wprowadzona do Katalogu Zabytków Sztuki w Polsce przez Tadeusza Chrzanowskiego i Mariana Korneckiego ${ }^{35}$; wzmiankował ją także Jerzy Łoziński ${ }^{36}$, który datował zabytek na lata 1370-80. Z kolei dwa popiersia ze zwieńczenia ołtarza znalazły się również na wystawie polskiej sztuki gotyckiej w 1935 roku $^{37}$, przy czym Michał Walicki wydatował je inaczej niż Piete, na lata ok. 1400 r., a w popiersiu biskupa upatrywał przedstawienia św. Klemensa. Później natomiast rzeźby te wzmiankował jedynie Clasen ${ }^{38}$, który uznał je za wykonane przez mistrza Piety i włączył do kręgu jednej z wykreowanych przez siebie, domniemanych pracowni prowincjonalnych kręgu toruńskiego (warsztat „Mistrza Ukrzyżowania z Gostkowa”). Prezentowane przez nie ujęcie formalne scharakteryzował jako prowincjonalne a nawet ludowe, posługując się określeniami „bäuerlich”, „grob”, „einfach” i „volkstümlich”. Tymczasem wszystkim trzem rzeźbom - faktycznie zbliżonym warsztatowo, należy się osobna analiza, gdyż uzupełniają one w istotny sposób stan naszej wiedzy o panoramie artystycznej toruńskiego ośrodka na przełomie XIV i XV wieku.

Świerczyńska Pieta (il. 5) to jedna z najciekawszych realizacji tego tematu, zachowana w przestrzeni kościoła wiejskiego w państwie zakonnym w Prusach. Wyróżnia się ona na tle innych przedstawień tego typu w dawnym państwie zakonnym wielką siłą pasyjnej ekspresji, uzyskaną dzięki dynamicznej formie i ostremu modelunkowi, pogłębiającemu efekty światłocieniowe. Dość dobra klasa tej figury w dużej mierze zafałszowana jest grubymi warstwami wtórnej, niestarannej polichromii. Warto jednak zaznaczyć, że mocne cięcia dłutem (czytelne mimo owych warstw) i twardy, syntetyczny modelunek to nie przejaw snycerstwa „ludowego" niskiej jakości. Mamy tu raczej do czynienia z próbą poprowadzenia formy w stronę silnego emocjonalizmu, dostosowanego swym oddziaływaniem do grona odbiorców, poszukujących bodźców wizualnych w ramach tzw. pobożności ludowej (co nie przesądza wcale o jej pierwotnym przeznaczeniu dla kościoła wiejskiego).

Maria ukazana jest jako starzejąca się niewiasta, odziana w obcisłą czerwoną suknię o płytkim dekolcie i długich mankietach, owinięta płaszczem. Jej głowę spowija maforium, nasunięte nisko na czoło. Twarz (il. 6) jest silnie zdeformowana bolesnym grymasem - z pooranym bruzdami czołem, wąskimi szparami zapuchniętych oczu i obrzmiałymi, wykrzy-

Zabytkami Przeszłości, Warszawa 1935, s. 16, nr kat. 9, il. tabl. VI.

32 Gwido ChMARZYŃski, Sztuka w Toruniu, [w:] Dzieje Torunia, red. K. TYMIEnIECKI, Toruń 1933, s. 469-544, zwł. s. 501.

33 Karl Heinz CLASEN, Die mittelalterliche Bildhauerkunst im Deutschordensland Preußen. Die Bildwerke bis zur Mitte des 15. Jahrhunderts, Berlin 1939, s. 199-200, kat. 565, s. 348.

34 Aleksandra i Zygmunt ŚWIECHOWSCY, Nieznane zabytki rzeźby na Warmii i Pomorzu Gdańskim, „Biuletyn Historii Sztuki” 13/1 (1951), s. 95-108, zwł. s. 101, przyp. 8 oraz s. 104.

35 KZSP 11/16, s. VIII oraz s. 66.

36 Jerzy Z. ŁOZIŃSKI, Pomniki sztuki w Polsce, t. 2, cz. 1, Pomorze, Warszawa 1992, s. 471.

37 WALICKI 1935, s. 17, nr 13-14.

38 CLASEN 1939, s. 199, kat. nr 566-567, s. 348 
wionymi wargami. Jej hieratycznie wyprostowana, zastygła postać o rozstawionych szeroko nogach buduje rodzaj tronu pod umęczone ciało Zbawiciela - nieco zbyt małe, niczym u Piet corpusculum. Ciało to jest wychudzone i nieforemne, o dużej głowie, dość szerokich ramionach, długim torsie i zbyt krótkich kończynach. Poza Chrystusa jest nienaturalnie sztywna. Jego plecy i ręce są wyprostowane; tors - lekko skręcony ku widzowi - ustawiony jest diagonalnie, krótkie nogi o wyolbrzymionych rzepkach kolanowych zwisają bezwładnie ku dołowi. Martwa twarz Zbawiciela, o zapadniętych, wpółprzymkniętych oczach, nacechowana jest silną ekspresją - „szczerzy” się szeregiem zębów, odsłoniętych w efekcie agonalnego cofnięcia żuchwy. Maria prezentuje Syna nienaturalnie lekko, a przy tym jakby troskliwie. Prawą dłonią podtrzymuje jego korpus, wskazując palcami na ranę w boku, lewą ręką zdaje się zagarniać ciało ku sobie.

Pod skrajnym, wizualnym emocjonalizmem ukryty jest głęboki apel religijny, wykraczający poza zachętę do pasyjnej, pokutnej kontemplacji. Charakterystyczny sposób prezentacji ciała, zwróconego en face ku widzom, może mieć podłoże eucharystyczne, podobnie jak ostentacja rany w boku, wiążąca się zapewne $\mathrm{z}$ kultem św. Krwi. Wpatrując się w to przedstawienie, widz zmaga się z mieszanymi emocjami, które wywołuje celowa ponadczasowość tego przekazu. O ile Maria, zastygła w niemej rozpaczy, jest niemal nieobecna i wyizolowana, to Chrystus - mimo, że ukazany w pośmiertnym skurczu - zdaje się być wciąż żywy, wpatrzony w widza, jakby z krzykiem chciał zerwać się z matczynych kolan, wyzwolić z jej ramion. Zwraca się ku wiernemu, zdaje się ku niemu wychodzić.

Cała ta kompozycja przywodzi na myśl dobre wzorce z kręgu nadreńskich i turyngeńskich Piet bolesnych - choć od „klasycznego” typu mistycznego różni ją zdecydowanie odmienna kompozycja ciała Chrystusa (na zbiegu typologii Piety „schodkowej” i „diagonalnej”) czy potraktowanie jego anatomii. To raczej artystyczny efekt niż realna typologiczna zależność nasuwają to skojarzenie, które skłoniło niegdyś Michała Walickiego ${ }^{39}$ i Gwidona Chmarzyńskiego ${ }^{40}$ do datowania dzieła na lata ok. 1350 r. i łączenia go z kręgiem Piet sasko -turyngeńskich. Niemniej jednak tchnie ono świadomością mistycznego typu corpusculum i zachodniej tradycji warsztatowej z pierwszej połowy XIV wieku. Szczególną uwagę zwraca typ i ekspresja starczego oblicza Marii, która występuje u pokrewnych typologicznie i czasowo figur z Żarnowca i Kijewa ${ }^{41}$.

Określenie genezy formalnej świerczyńskiego zabytku nie znalazło dotąd trafnego rozwiązania. Wydaje się, iż podobnie jak w przypadku dzieł późnogotyckich ze Świerczynek, i tu można szukać warsztatowych korzeni w pracowni lokalnej, toruńskiej. Doprowadzenie ekspresyjnego doloryzmu dzieła do skrajności nadaje mu nieco prowincjonalnego odczucia i tłumaczy po części ogólną obserwację Chrzanowskiego i Korneckiego, którzy związali

39 WALICKI 1935, s. 16.

40 CHMARZYŃSKI 1933, s. 501.

41 Rzeźby te pochodzą jeszcze sprzed „eksplozji” przedstawień dewocyjnych, jaka nastąpiła w pierwszej ćwierci XV wieku, ich dokładne artystyczne korzenie - choć zapewne zachodnie - nie są do końca jasne. Zob. na ich temat m.in. ŚWIECHOWSCY 1951, s. 99-104: autorzy datują oba zabytki przed rokiem 1400, widząc w nich ogniwo pośrednie pomiędzy dziełem ze Świerczynek a grupą Piet wykonanych w stylu międzynarodowym. 
rzeźbę - jako „sprymitywizowaną formalnie” - z kręgiem apostołów brodnickich ${ }^{42}$, a więc szerzej - z „Madonnami na lwach”. Propozycję tę należy jednak poddać istotnej rewizji. Echo konwencji „Madonn na lwach” (por. il. 7) faktycznie zdaje się pobrzmiewać w tym dziele. Fizjonomia Marii jest zdeformowana przerysowaną mimiką; jej szeroka twarz, o bardzo wysokim czole i charakterystycznie wypukłej bródce naznaczonej dziurką, wykrzywia się w sztucznym grymasie, który wrysowuje w centralną partię oblicza trójkąt utworzony przez bardzo szerokie skrzydełka nosa, bruzdy okołonosowe i szerokie, grube usta ( $\mathrm{z}$ charakterystyczną wypukłością w górnej wardze). Za znamiona stylu „Madonn na lwach” można by też uznać pewne cechy pozy - nierówny układ stóp, opuszczonych po bryle podstawy oraz detale stroju - wykrój dekoltu, przedłużone mankiety wąskich rękawów, a także formę niektórych szczegółów - np. twardo ciętych dłoni, o skróconym śródręczu i niemal równych, walcowatych palcach. W skazuje to, iż autor Piety mógł być obeznany z najpopularniejszą konwencją snycerstwa pruskiego w XIV stuleciu, co jednak nie przesądza o warsztacie ani o datowaniu dzieła.

Figura świerczyńska jest od rzeźb kręgu „Madonn na lwach” dużo bardziej przestrzenna (postaci Chrystusa i Marii są pełnoplastyczne); w przeciwieństwie do nich, nie jest przeznaczona wyłącznie do oglądu en face, co zmienia całkowicie system formy. Pozbawiona jest ona dążności do iluzji poprzez nierówne ustawienie nóg. Wprawdzie stopy Marii są nienaturalnie opuszczone ku dołowi, lecz ustawiono je niemal w jednej linii. Nie ma tu również płaskich, kaligraficznych pofałdowań o dynamicznym rysunku. Sfałdowanie dolnej partii szat Madonny - podporządkowane rygorystycznej, symetrycznej kompozycji - potraktowane jest dużo bardziej miękko i przestrzennie. Ta kompozycyjna odmienność nie tłumaczy się odmiennym tematem, jest on zresztą raczej obcy kręgowi „Madonn na lwach” ${ }^{43}$. Uwalniając się więc od ogólnego „pierwszego wrażenia”, które kazało innym badaczom szukać analogii z rzeźbami tej specyficznej konwencji, warto zwrócić również uwagę na te cechy formy, które wskazują na odmienną stylistykę i nieco późniejszą metrykę dzieła. Należy do nich przykładowo modelunek wydłużonego torsu Chrystusa z "gruzełkowato” potraktowaną, dość miękką anatomią lub typ perizonium - ciasno owiniętego wokół bioder, sięgającego powyżej kolan i pozbawionego dekoracyjnych festonów, charakterystycznych dla większości Piet i krucyfiksów z XIV wieku.

Tak ukształtowana postać umęczonego Zbawiciela znajduje swą dokładną - choć stojącą na wyższym poziomie artystycznym - analogię w figurze Chrystusa w Grobie z kościoła pofranciszkańskiego w Toruniu (il. 8). Rzeźbie tej poświęciliśmy swego czasu osobne studium, datując ją na lata ok. 1400 r. i włączając jej afektywną formę w nurt tzw. turpizmu gotyckiego, funkcjonujący na marginesie stylu międzynarodowego ${ }^{44}$. Na oryginalny charak-

42 KZSP 11/16, s. VIII.

43 Typ Piety jest obcy zarówno tradycji ikonograficznej kręgu „Madonn na lwach”, jak i ołtarzowym funkcjom większości dzieł. O tradycji ikonograficznej tego kręgu, zob. Zofia BIAŁŁOWICZ-KRYGIEROWA, Studia nad snycerstwem XIV wieku w Polsce, cz. 1, Początki śląskiej tradycji ołtarza szafowego, („Prace Komisji Historii Sztuki”, t. 12), Poznań 1981, s. 33-78.

44 Monika JAKUBEK-RACZKOWSKA, Juliusz RACZKOWSKI, Gotycka figura Chrystusa w Grobie i jej miejsce w przestrzeni liturgicznej kościoła franciszkanów w Toruniu, [w:] DZIEJE I SKARBY 2005, s. 181-202. 
ter artystyczny Chrystusa w Grobie złożyły się czynniki o różnej genezie. „Podkładem” dla efektu monumentalizacji mogła być tradycja plastyki monumentalnej - być może o czeskośląskim lub południowoniemieckim (frankońskim) rodowodzie. Sposób ekspresyjnej stylizacji, podobnie jak u Piety ze Świerczynek, sięgał jednak do snycerskiej tradycji „nurtu mistycznego" i crucifixi dolorosi lat około 1300-1350 r., z której można wywieść także technikę wykonania kształtowanych w zaprawie skrzepów krwi wokół ran.

Porównanie obu dzieł pozwala uznać Pietę ze Świerczynek za pracę tego samego warsztatu. Choć proporcje postaci Zbawiciela nieco się różnią (co wynika ze skali rzeźb i założeń kompozycyjnych), jego anatomia nosi zbliżone cechy i modelowana jest z podobną tendencją do syntetyzmu. Szerokie ramiona są zestawione z dość szczupłym, wydłużonym torsem, mocna szyja wchodzi między plastyczne obojczyki, ścięgna ramion są cięte ostro a kosz klatki piersiowej formuje spłaszczony ostrołuk. Kościec torsu jest formowany miękko, płasko i rytmicznie - wgłębienia trzonu mostka, schematyczne linie żeber. W przypadku Chrystusa w Świerczynkach należy przypuszczać, że wokół rany w boku znajdowało się pierwotnie grono kropli krwi, podobnie jak na stopach ukształtowane w gruncie. Porównanie twarzy obu przedstawień Zbawiciela również nie pozostawia wątpliwości (por. il. 9, 10). Za wspólną proweniencją warsztatową przemawiają proporcje oblicza - wydłużonego i okolonego analogicznie formowanymi pasmami włosów; sposób oddania bolesnej ekspresji mimicznej poprzez głęboko zapadnięte oczodoły, ukośnie wygięte, grube łuki brwiowe; wreszcie szczegóły - kształt oczu, prosty nos o wydatnych skrzydełkach, mocno cięte bruzdy przynosowe, grube usta z obrzmiałą górną wargą, w których widać rząd zębów. Stylizacja mimiki bolejącej Marii, którą ukazaliśmy wyżej w zestawieniu ze zdeformowaną fizjonomią „Madonn na lwach”, daje się z większym powodzeniem przyrównać do ekspresji twarzy toruńskiego Chrystusa w Grobie. Uderzają analogiczne proporcje twarzy, głęboka bruzda w kształcie litery „V” pomiędzy zgrubiałymi łukami brwiowymi, wydatny nos o masywnych skrzydełkach oraz obrzmiały guzek w górnej wardze.

Jak już wspomniano, pierwotna proweniencja rzeźby nie jest pewna. Figura jest $\mathrm{z}$ tyłu wydrążona, co wskazuje, iż musiała stać w niszy ściennej lub wkomponowana była w rodzaj dorsale (obudowę z zapleckiem i baldachimem). Nie została ona odnotowana w wizytacjach biskupa Olszowskiego, co jednak nie przemawia jeszcze przeciw jej związkowi ze Świerczynkami, gdyż sprawozdania XVII-wiecznych wizytacji pomijały wiele elementów wyposażenia „dewocyjnego” kościołów wiejskich, skupiając się na ołtarzach, utensyliach i paramentach liturgicznych. Zwraca jednak uwagę, iż obecne miejsce ekspozycji rzeźby jest wtórne - stoi ona w płytkiej niszy podokiennej, cofnięta za ołtarz główny, oddzielona sporym dystansem od wiernych. Tak umiejscowiona, nie mogłaby służyć swej podstawowej funkcji - przedstawienia dewocyjnego, pobudzającego nastroje pokutne. Wprawdzie temat ten ani funkcja nie są obce kościołom wiejskim państwa zakonnego w tym okresie, Pieta świerczyńska byłaby jednak w ich gronie jednym z najstarszych przykładów. Tezy o jej pochodzeniu od benedyktynek ${ }^{45}$ nie da się więc całkowicie odrzucić - jej temat i ekspresyjna forma, bliska pobożności gminu, mogła z powodzeniem znaleźć swe miejsce w kościele 
szpitalnym. Z drugiej strony, wskazany związek warsztatowy z Chrystusem w Grobie nie pozwala wykluczyć i takiej możliwości, że figura stanowiła ważny element wyposażenia przestrzeni świątyni Mariackiej w Toruniu. Wpisana we franciszkański nurt pasyjny o cechach mistyki i silnego doloryzmu, w prosty i mocny sposób afektywna (podobnie jak Chrystus w Grobie), mogłaby tam z powiedzeniem służyć mendykanckiemu programowi duszpasterskiemu, nakierowanemu na spowiedź, pokutę i nawrócenie.

Pozostaje zadać pytanie o dwa popiersia ze zwieńczenia świerczyńskiej nastawy, które Clasen widział w łączności z Pietą. Choć nie ma żadnych danych na temat ich pierwotnej proweniencji, które pozwalałyby przyjąć lub odrzucić ich związek z wiejską świątynią lub wyciągnąć wnioski na temat zależności warsztatowych, można postawić kilka roboczych hipotez. Zarówno popiersie świętego biskupa (il. 11), jak i głowa brodatego mężczyzny (il. 12 a,b), wydają się być fragmentami większych rzeźb gotyckich, przerobionych z czasem na popiersia, przy czym w przypadku św. biskupa uformowanie wskazuje w dodatku na wtórną funkcję relikwiową (przeróbka na hermy musiała więc nastąpić wcześniej niż osadzenie tych reliktów w nastawie ołtarzowej $\left.{ }^{46}\right)$. Postać brodatego mężczyzny, pierwotnie półnaga, a rozpoznana przez Clasena jako św. Jan Chrzciciel, może być też fragmentem dawnego przedstawienia chrystologicznego, choć kwestii tej - wobec wspomnianych przekształceń - nie da się rozstrzygnąć. Wydaje się, iż oba te dzieła są pozostałością po jednej gotyckiej nastawie ołtarzowej z początku XV wieku, o dość dużych rozmiarach ${ }^{47}$.

Za Clasenem można przyjąć tożsamość warsztatową obu tych reliktów i świerczyńskiej Piety. Wskazują na to proporcje twarzy o wydatnych nosach i grubych ustach oraz ekspresyjne wygięcie ostro ciętych brwi. Popiersia wykazują zresztą analogie z toruńskim Chrystusem w Grobie. W przypadku ascetycznej fizjonomii św. biskupa, uwagę w tym zestawieniu zwracają twardo ścięte policzki, wygięte brwi, głębokie oczodoły, wydatny nos. U drugiego popiersia oprócz cech fizjonomii trzeba też wziąć pod uwagę sposób syntetycznego opracowania włosów i zarostu za pomocą równoległych pociągnięć dłuta.

W świetle przytoczonej analizy, Pieta ze Świerczynek i dwa popiersia, zdobiące nastawę ołtarza głównego, wydają się być dziełami toruńskiego warsztatu Chrystusa w Grobie powstałymi na przełomie XIV i XV wieku. Byłyby to kolejne dające się zidentyfikować prace tego warsztatu obok hermy św. Klary, którą związała z nim wcześniej Elżbieta Pilecka ${ }^{48}$. Jego charakter stylowy ukształtował się na styku różnych konwencji rzeźby XIV-wiecznej, z czy-

46 Nie byłby to jedyny w sztuce Torunia przykład adaptacji rzeźby na popiersie relikwiowe w okresie nowożytnym - dobrą analogią jest tzw. relikwiarz św. Klary w kościele św. Jana w Toruniu. Pełnoplastyczna, opracowana ze wszystkich stron głowa wraz z nasadą ramion (29 cm wys.), została odjęta prawdopodobnie od całopostaciowej figury świętej niewiasty. Ok. 1620 r. nastąpiło jej wtórne osadzenie na graniastym cokole i przeszklonej skrzynce relikwiarzowej. Zob. Juliusz RACZKOWSKI, Relikwiarz hermowy św. Klary z kościoła św. Janów w Toruniu, hasło [w:] Fundacje artystyczne na terenie państwa krzyżackiego w Prusach. Katalog wystawy w Muzeum Zamkowym w Malborku, t. 1, red. B. POSPIESZNA, Malbork 2010, s. 274.

47 Popiersia mierzą 35 i $44 \mathrm{~cm}$ (św. Biskup). Jeśli więc założyć, że są to fragmenty statui całopostaciowych, trzeba by przyjąć ich dość duże (zbliżone do naturalnych) rozmiary.

48 Elżbieta PILECKA, Kościół p.w. św. Jana Chrzciciela i Jana Ewangelisty w Toruniu w okresie średniowiecza jako wizualizacja świadomości społecznej, [w:] Dzieje i skarby kościoła Świętojańskiego w Toruniu. Materiały z konferencji przygotowanej przez Toruński Oddział SHS w X rocznicę ustanowienia Diecezji Toruńskiej, 22-23 marca 2002, red. K. KLUCZWAJD i M. WOŹNIAK, Toruń 2002, s. 119-176, zwł. s. 156. 
telnym wpływem dość już archaicznej tradycji technologicznej kręgu nadreńskiego. Indywidualnym desygnatem tej pracowni była natomiast silna ekspresja pozbawionych idealizmu przedstawień, o twardo modelowanych zwartych bryłach, syntetycznie traktowanych szczegółach, słabo poruszonej - choć głęboko ciętej draperii i typie oblicza, dla którego charakterystyczne były wyraziste mocne rysy i prostolinijne emocje. Stworzony przez Karla Heinza Clasena obraz produkcji warsztatowej w średniowiecznym Toruniu, zdominowany przez „teorię jednego mistrza” („Mistrz Ukrzyżowań Toruńskich”, „Mistrz Pięknych Madonn”, „Mistrz Ukrzyżowania z Chełmży”), okazał się anachroniczny i nie wytrzymał krytyki. Badania ostatniej dekady proponują nowe spojrzenie na twórczość tego ośrodka, w której obok znaczących importów zaczynają rysować się grupy dzieł miejscowych, na styku różnych tradycji kształtujące wewnętrzny - lokalny - charakter sztuki Torunia.

Problem pochodzenia świerczyńskiego zespołu rzeźbiarskiego (z wyjątkiem ołtarzowej, późnogotyckiej Marii z Dzieciątkiem) musi pozostać otwarty. Trwające po wiek XIX powiązanie wsi z konwentem toruńskich benedyktynek jest pewną wskazówką dla poszukiwań ich ewentualnej pierwotnej lokalizacji w którejś ze świątyń, pozostających pod opieką mniszek. Z drugiej strony warsztatowe zależności rzeźb od dzieł, stanowiących wyposażenie kościoła NMP w Toruniu, nie pozwala przejść obojętnie wobec możliwości ich pofranciszkańskiej (względnie - pobernardyńskiej) proweniencji. Biorąc pod uwagę burzliwe dzieje religijne miasta ${ }^{49}$, których efektem były rozmaite translokacje pozostałości dawnych wyposażeń sakralnych, można z powodzeniem założyć, iż cztery średniowieczne rzeźby ze Świerczynek - Pieta, dwa popiersia i grupa Paternitas - należą do pokasacyjnego dziedzictwa Torunia.

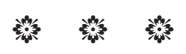

\section{Gothic sculptures in the church in Siwierczynki. A contribution to the studies on the Mediaeval heritage of Torun}

St John's parish in Swierczynki village near Torun since the beginning was related with the dynamic process of building parish network of Ziemia Chetminska. Gothic church was built in the $2^{\text {nd }}$ quarter of $14^{\text {th }}$ century as one of the oldest three-segment village temples. Over the time the history of parish interweaved with the history of the only female convent in Mediaeval Torun - from mid $14^{\text {th }}$ to mid $19^{\text {th }}$ century it remained under the patronage of the Cistercian-Benedictine nuns.

The church - next to a high quality early modern furnishing - houses a non-homogenous

49 Zob. m. in. Tadeusz GLEMMA, Stosunki kościelne w Toruniu w stuleciu XVI i XVII na tle dziejów kościelnych Prus Królewskich, („Roczniki Towarzystwa Naukowego w Toruniu” 42), Toruń 1934; Kazimierz MALISZEWSKI, Stosunki religijne $w$ Toruniu $w$ latach 1548-1660, [w:] Historia Torunia, red. M. BISKUP [dalej cyt. HISTORIA TORUNIA], t. 2, cz. II: W czasach renesansu, reformacji i wczesnego baroku, Toruń 1994, s. 257-300; Stanisław SALMONOWICZ, Dzieje wyznań i życia religijnego, [w:] HISTORIA TORUNIA, t. 2, cz. III: Między barokiem i oświeceniem, Toruń 1996, s. 395-418; Elżbieta ALABRUDZIŃSKA, Stosunki religijne w Toruniu (1815-1914), [w:] HISTORIA TORUNIA, t. 3, cz. I, W czasach zaboru pruskiego (1793-1920), Toruń 2003, s. 390-419. 
set of five good quality Gothic sculptures of a secondary location in the liturgical space. Except of the free-standing Pieta they have been incorporated in the structure of a late-Baroque retable of the high altar (1696): Virgin with the Child in the centre of the retable and a Pietas Domini group in the crowning as well as two older busts of Saints on the moulding. Their original connection with the church is not confirmed.

The figures belong to two different stylistic groups. The devotional rendering of Virgin with the Child, dressed in a late-Baroque, $18^{\text {th }}$ cent., garment (most probably being the part of church furnishing from its very beginning) together with the Pietas Domini belong to the later one, often mentioned in the literature. Those historic artefacts, dated back to the turn of $15^{\text {th }}$ century, are related with the activities of two late-Mediaeval woodcarvers' ateliers active in Torun. Older sculptures are the work of one atelier. In the earlier literature they have not been properly recognised - presented analysis argues its stylistic relations with the figure of Christ in Tomb in the former Greyfriars' church. That atelier was active in Torun at the turn of $14^{\text {th }}$ century and its individual designation was strong expression of sculptures that had roughly modelled faces, compact bulk, synthetic detail and characteristic faces' type (expressive, strong features and straightforward emotions). This assignation makes an important contribution to the development of a new vision of the atelier dynamics of artworks in Mediaeval Torun, where next to a significant group of imported works one can distinguish groups of locally made ones, that shape the local character of that centre on the border of various traditions.

The issue of origin of the group of sculptures in Swierczynki (except for the late-Gothic Virgin with the Child in the altar) has to remain open. Taking into consideration stormy religious history of the town and the resulting translocations of the remnants of older church furnishing, one can make a justified assumption that four Mediaeval sculptures in Świerczynki belong among the elements of heritage scattered after dissolving the religious orders in Torun and went to this village church from the convent of Benedictine nuns or form the Grey Friars (or perhaps the Bernadine monks). 


\section{SPIS ILUSTRACJI}

1. Kościół par. św. Jana w Świerczynkach, widok prezbiterium z ołtarzem głównym, fot. J. Raczkowski.

2. Świerczynki, Madonna z Dzieciątkiem w ołtarzu głównym, a) przed konserwacją, b) stan obecny, fot. J. Raczkowski

3. Świerczynki, Madonna z Dzieciątkiem w ołtarzu głównym, fot. M. Jakubek-Raczkowska.

4. Świerczynki, grupa Pietas Domini w zwieńczeniu ołtarza głównego, fot. J. Raczkowski.

5. Świerczynki, grupa Pieta, fot. J. Raczkowski.

6. Świerczynki, grupa Pieta - fragment, głowa Marii, fot. J. Raczkowski.

7. Pietrzwałd k. Sztumu, kościół par., figura św. Wawrzyńca - fragment, Muzeum Diecezjalne w Pelplinie, fot. J. Raczkowski.

8. Toruń, kościół NMP, Chrystus w Grobie, depozyt parafii w Muzeum Okręgowym w Toruniu, fot. J. Raczkowski.

9. Toruń, kościół NMP, Chrystus w Grobie - fragment, fot. J. Raczkowski.

10. Świerczynki, grupa Pieta - fragment, głowa Chrystusa, fot. J. Raczkowski.

11. Świerczynki, popiersie św. Biskupa na gzymsie ołtarza głównego, fot. J. Raczkowski

12. Świerczynki, popiersie nieznanego świętego, św. Jan Chrzciciel (?), na gzymsie ołtarza głównego, a-b, fot. J. Raczkowski. 


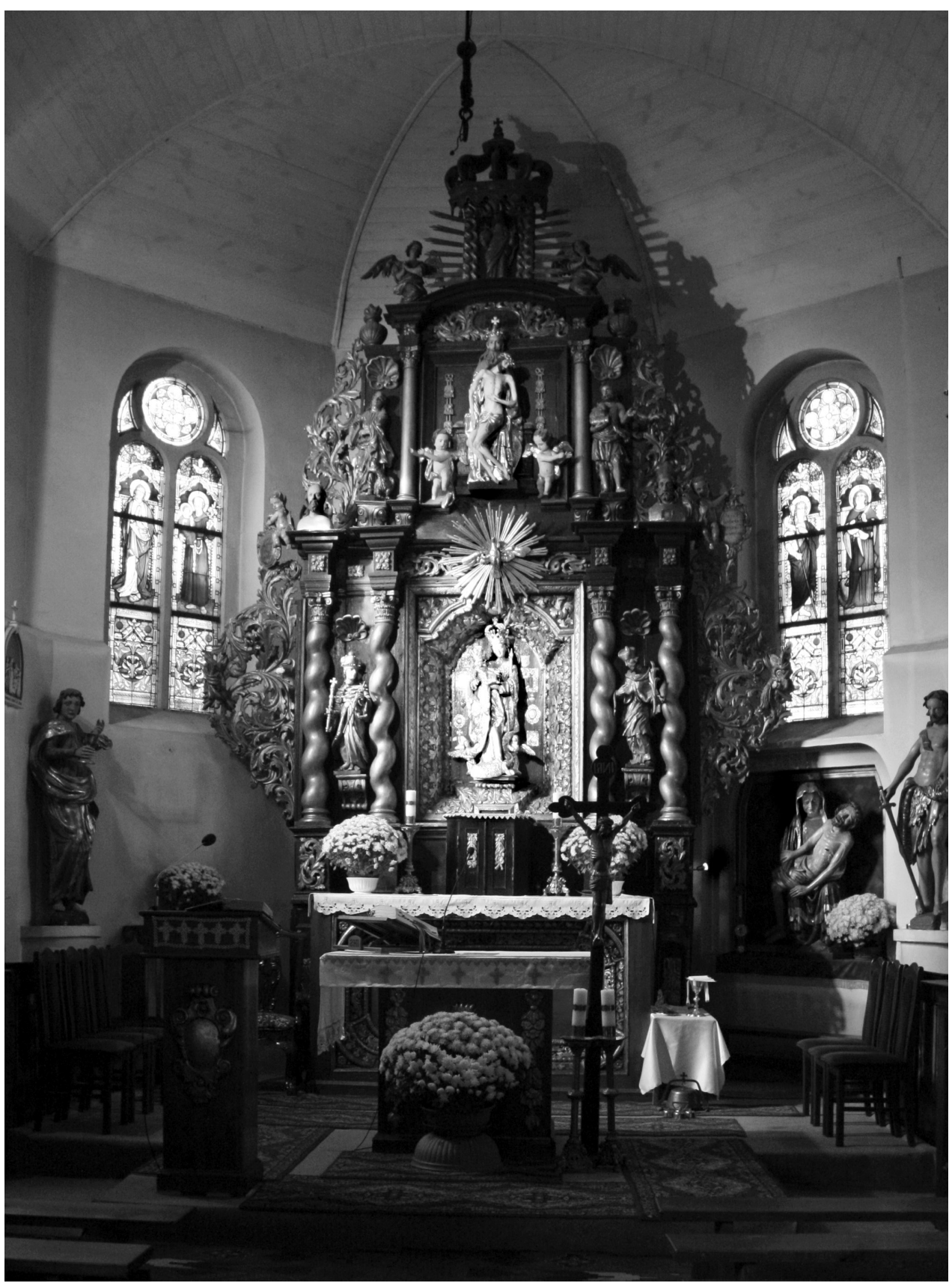

Il. 1 Kościół par. św. Jana w Świerczynkach, widok prezbiterium z ołtarzem głównym, fot. J. Raczkowski 

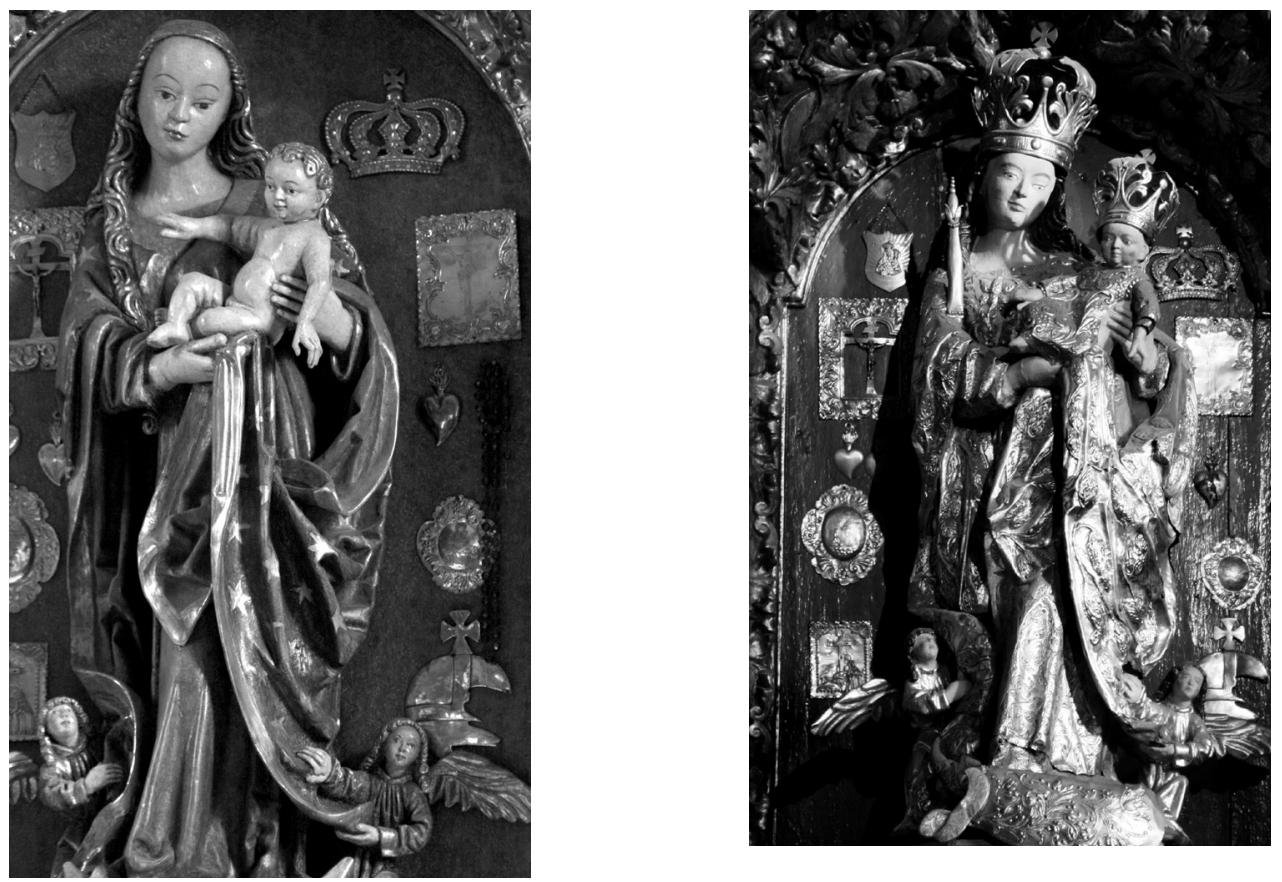

Il. 2 Świerczynki, Madonna z Dzieciątkiem w ołtarzu głównym, a) przed konserwacją, b) stan obecny, fot. J. Raczkowski

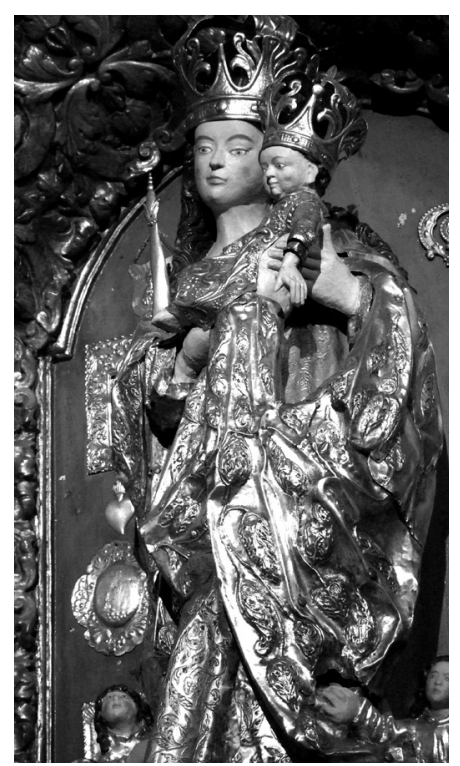

Il. 3 Świerczynki, Madonna z Dzieciątkiem w ołtarzu głównym, fot. M. Jakubek-Raczkowska

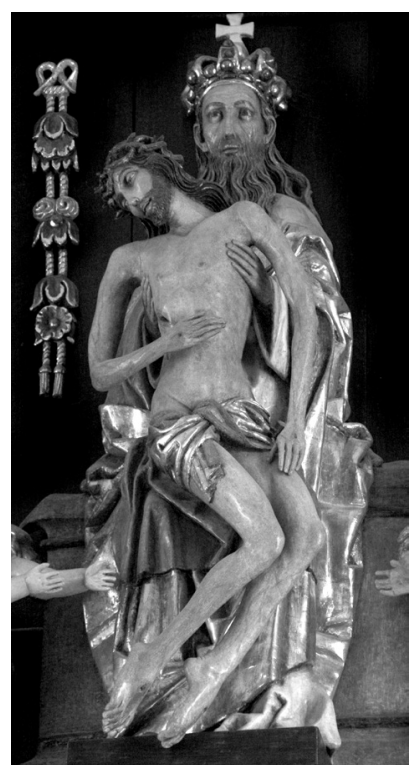

Il. 4 Świerczynki, grupa Pietas Domini w zwieńczeniu ołtarza głównego, fot. J. Raczkowski 

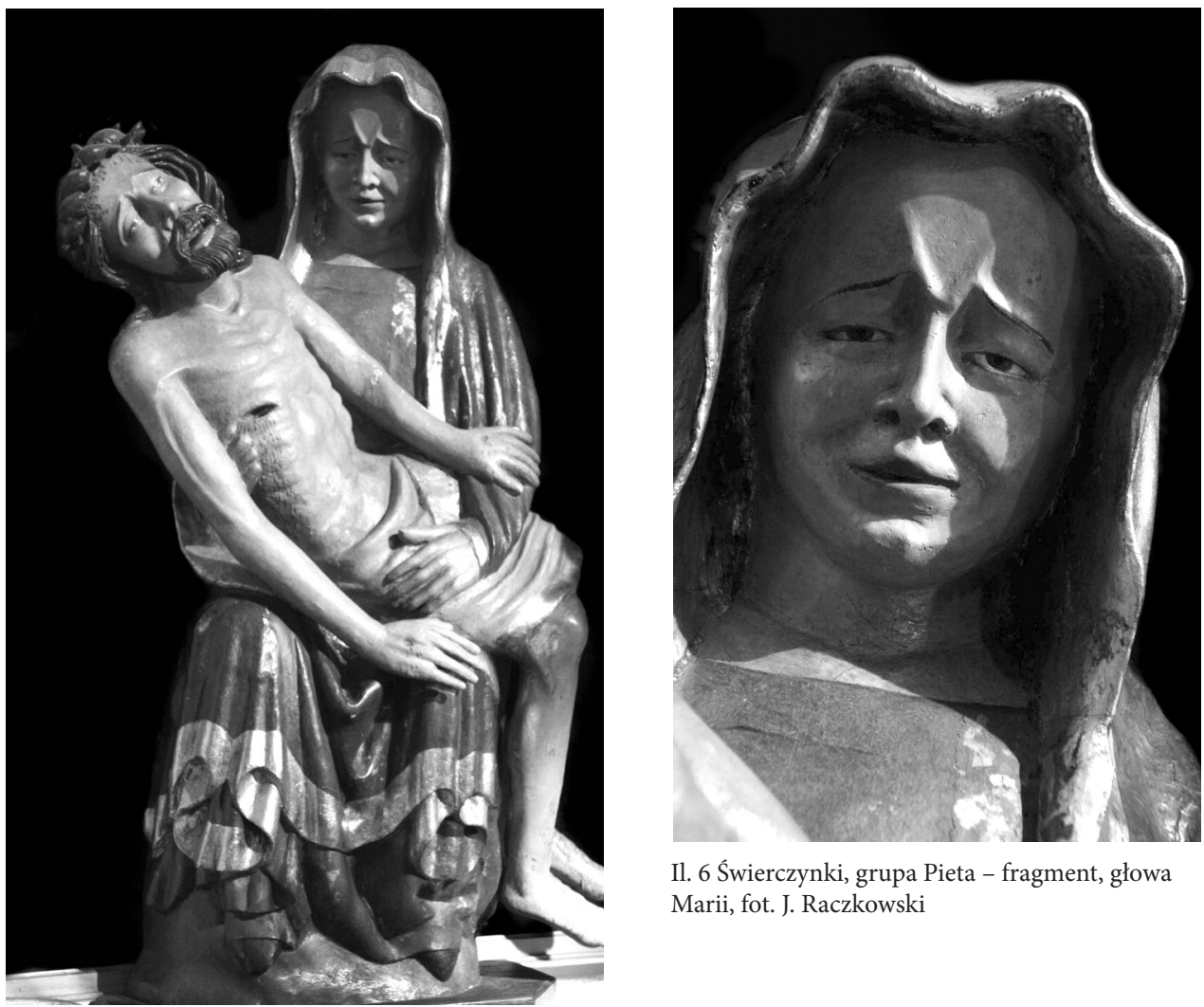

Il. 6 Świerczynki, grupa Pieta - fragment, głowa Marii, fot. J. Raczkowski

Il. 5 Świerczynki, grupa Pieta, fot. J. Raczkowski

Il. 7 Pietrzwałd k. Sztumu, kościół par., figura św. Wawrzyńca - fragment, Muzeum Diecezjalne w Pelplinie, fot. J. Raczkowski

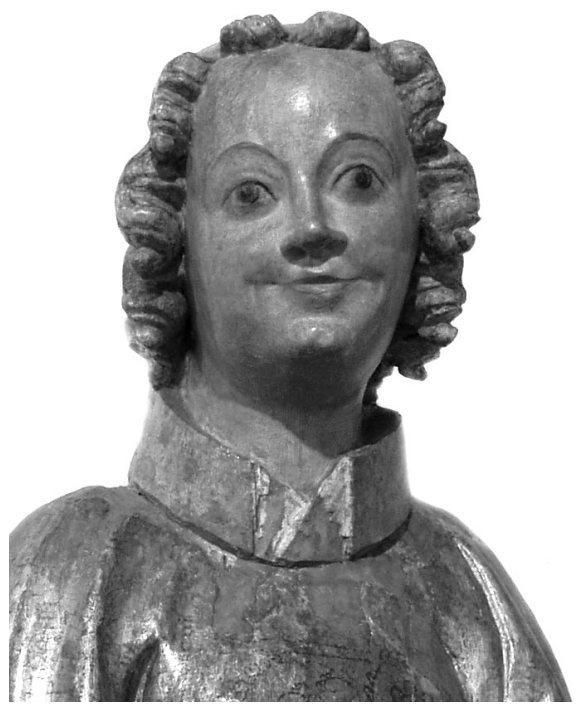




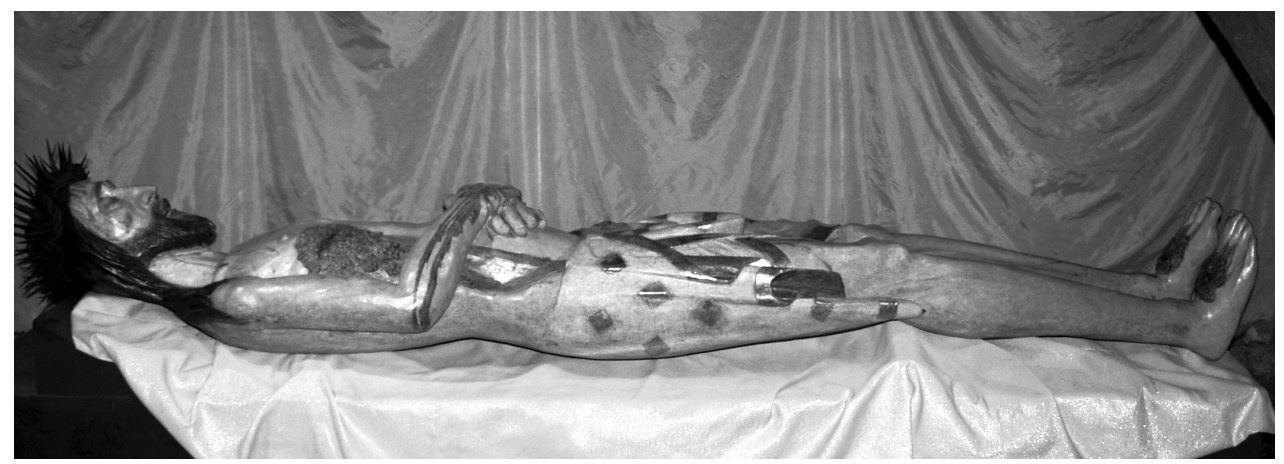

Il. 8 Toruń, kościół NMP, Chrystus w Grobie, depozyt parafii w Muzeum Okręgowym w Toruniu, fot. J. Raczkowski

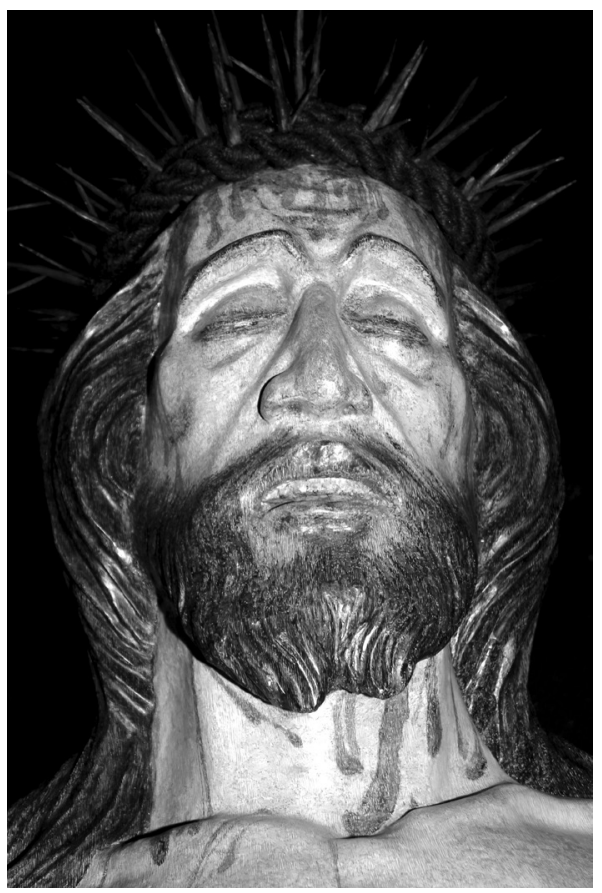

Il. 9 Toruń, kościół NMP, Chrystus w Grobie - fragment, fot. J. Raczkowski

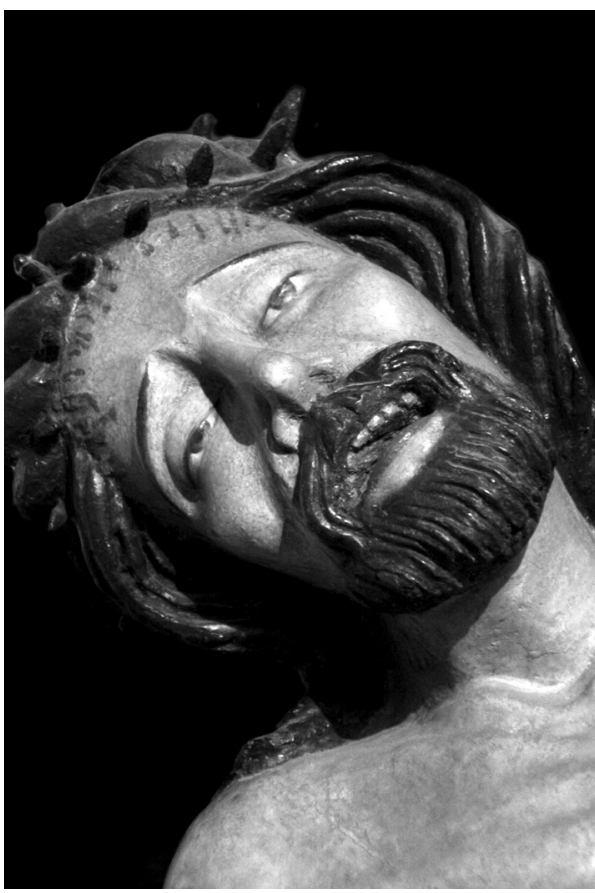

Il. 10 Świerczynki, grupa Pieta - fragment, głowa Chrystusa, fot. J. Raczkowski 


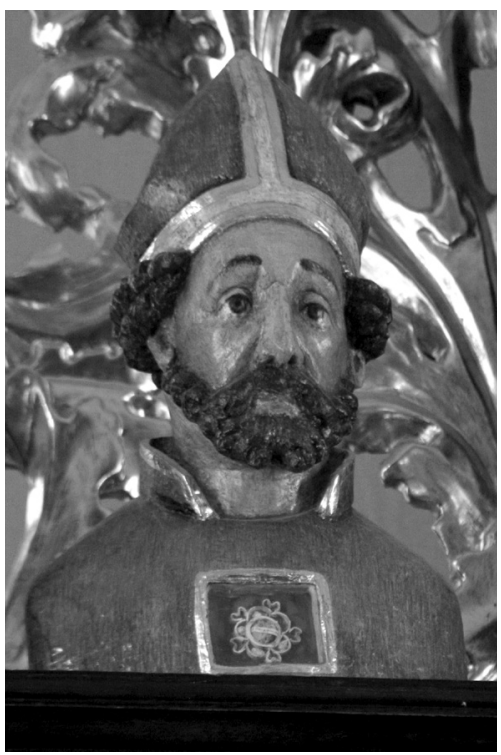

Il. 11 Świerczynki, popiersie św. Biskupa na gzymsie ołtarza głównego, fot. J. Raczkowski
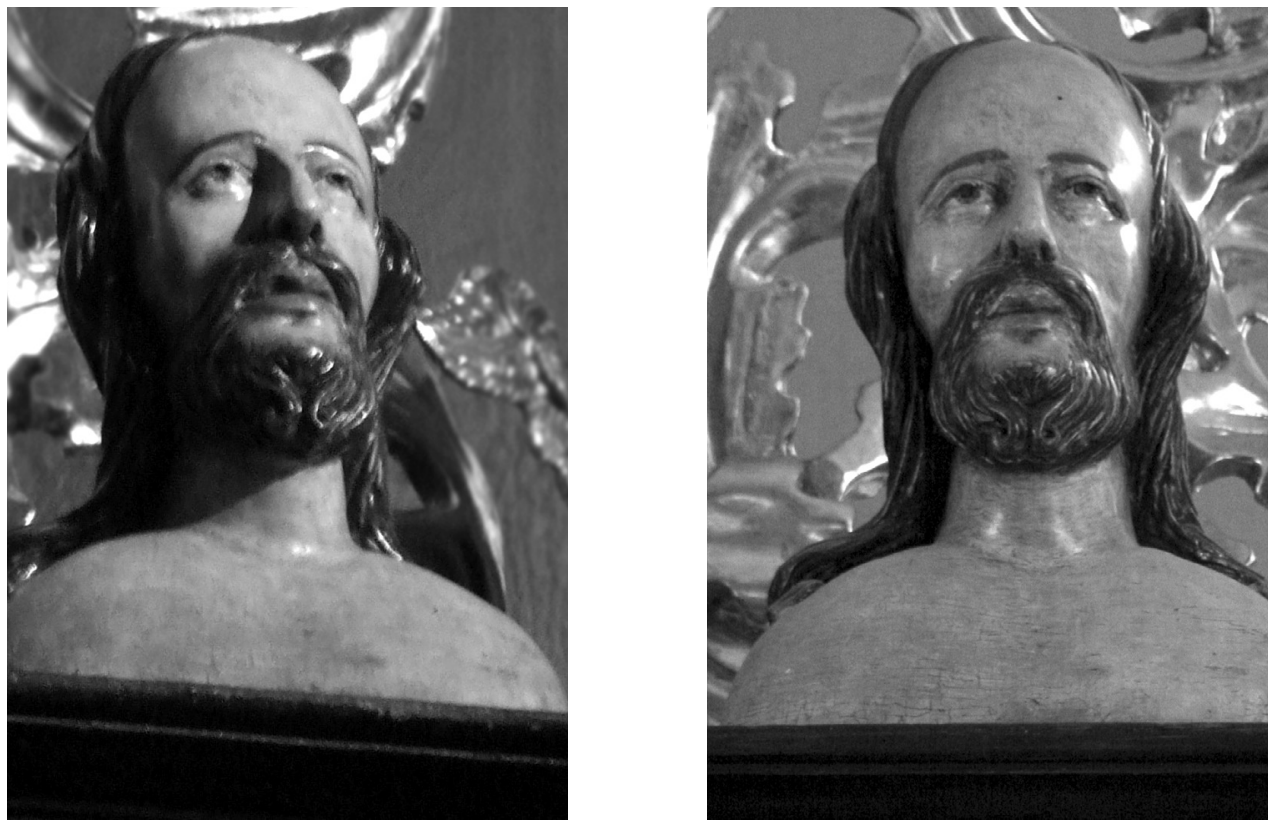

Il. 12 Świerczynki, popiersie nieznanego świętego, św. Jan Chrzciciel (?), na gzymsie ołtarza głównego, a-b, fot. J. Raczkowski 